\title{
GENPI'S STRATEGY IN THE DEVELOPMENT DIGITAL TOURISM DESTINATION IN LAMPUNG PROVINCE
}

\author{
Dian Kagungan ${ }^{1}$, Anna Gustina Zainal ${ }^{2}$, and Feni Rosalia ${ }^{3}$ \\ ${ }^{1}$ Public Administratio ${ }^{1}$, University of Lampung, \\ ${ }^{2}$ Communication Department, University of Lampung, \\ ${ }^{3}$ Goverment Departement, University of Lampung \\ Jl. Sumantri Brojonegoro No. 1 Gedung Meneng, Bandar Lampung \\ Email: dian.kagungan@fisip.unila.ac.id'i ; anna.gustina@fisip.unila.ac.id ${ }^{2}$; feni.rosalia@fisip.unila.ac.id³
}

\begin{abstract}
Provincial tourism development Lampung is the leading tourist destination in Indonesia the locomotive of development and provide increased welfare on Public. This research aims to determine GenPi's strategy in developing a policy digital tourism destination towards Lampung go digital. The method in this research is qualitative, the location of this research is Tahura Market, Teluk Pandan District, Pesawaran Regency, Lampung Province. Data were collected through interviews and FGDs, The informants in this study were the administrators of GenPi Lampung, two administrators of Tahura Market, and two visitors to Tahura Market tours. Based on the research results GenPi's startegy, it is known to encouraging the development of tourism in Lampung, GenPI Lampung plays an important role in developing tourism in Lampung by carrying out vigorous promotions on social media, one of which is by sending content on tourist destinations in Lampung to thep latform GenPi.co. GenPI Lampung also carries out activities offline, one of which is by creating a digital tourism destination in the form of a market. Digital tourism destination is the result of demands of era the digital considering the dominated today's travelers generation, millennials tend to like the visit to destinations that provide new and fun experience. The concept of digital tourism destination refers to a destination that is creative, has photogenic spots to upload on social media, and goes viral on social media.
\end{abstract}

Key word: Strategy; tourism; digital; development; social media

\section{STRATEGI GENPI DALAM UPAYA MENGEMBANGKAN DIGITAL TOURISM DESTINATION DI PROVINSI LAMPUNG}

\begin{abstract}
ABSTRAK. Pengembangan pariwisata Provinsi Lampung adalah sebagai daerah tujuan wisata terdepan di Indonesia yang menjadi lokomotif pembangunan dan memberikan peningkatan kesejahteraan pada masyarakat. Penelitian ini bertujuan untuk mengetahui startegi GenPi dalam mengembangkan kebijakan digital tourism destination menuju Lampung go digital. Metode dalam penelitian ini kualitatif, lokasi penelitian ini Pasar Tahura Kecamatan Teluk Pandan, Kabupaten Pesawaran Propinsi Lampung. Data dipetik melalui wawancara dan FGD, informan dalam penelitian ini adalah pengurus GenPi Lampung, dua orang pengurus Pasar Tahura dan dua orang pengunjung wisata Pasar Tahura. Berdasarkan stratgei GenPi Lampung untuk mendorong semakin berkembangnya pariwisata di Lampung, GenPI Lampung mengambil peran penting dalam mengembangkan pariwisata di Lampung dengan dilakukannya promosi yang gencar di media-media sosial, salah satunya dengan mengirimkan kontenkonten destinasi wisata di Lampung ke platform GenPi.co. GenPI Lampung juga melakukan kegiatan offline, salah satunya dengan menciptakan digital tourism destination dalam bentuk pasar rakyat. Digital tourism destination merupakan hasil dari tuntutan era digital mengingat wisatawan zaman sekarang yang didominasi generasi millenial, cenderung menyukai berkunjung ke destinasi yang memberikan pengalaman baru dan menyenangkan. Konsep digital tourism destination ini mengacu pada destinasi yang kreatif, memiliki spot fotogenik untuk diunggah di media sosial, dan viral di media sosial.
\end{abstract}

Kata kunci: Strategi; pariwisata; digital; pembangunan; media sosial

\section{INTRODUCTION}

Tourism in Indonesia is one of them the national leading sector and is also expected to become leading sectors in foreign countries, especially in the region ASEAN. However, the current reality shows that Indonesia's tourism ranking in foreign countries yet superior to other countries, including existing countries in the ASEAN region. This can be seen based on data on the number of visits by foreign tourists as well ranking of Indonesia's tourism competitiveness in ASEAN which is still under the state of Malaysia, Singapore, and Thailand (Ahmad, 2018).

The tourism sector is one of the largest contributors to the economy in Indonesia (Nurhadi, 2014), tourism is one of the sectors that has an important role in the development of a country, because tourism is considered directly and can contribute more to the revenue of the area where the tourist attraction is located. The tourism sector can be used as one of the leading sectors in efforts to earn foreign exchange (Larsen \& Wolff, 2016), job creation and poverty alleviation (Della, Sciarrelli, \& 
Del Gaudio, 2015). The same explanation was also conveyed that the tourism sector plays an important role in the Indonesian economy (Meiwany, Tapatfeto, \& Juita, 2018), both as a source of foreign exchange earnings and job creation and business opportunities (Heliany, 2019).

Currently tourism is one of the most threatened sectors due to the Corona virus pandemic (Jayadi \& Suryawan, 2020), including in Lampung Province, precisely in Pesawaran District. Which are strategic areas for the center of Lampung tourism development. Indonesian tourist visits from 2014 to 2019 continued to increase. In 2014 the number of domestic and foreign tourists was 4.4 million and in 2019 the number of tourists reached 10.7 million.

Foreign tourist visits since 2014 have continued to increase, while the highest number of domestic tourist visits was in 2018, reaching 13.8 million (Lampung Province Tourism, 2018). The graph of the development of the number of tourist visits can be seen as follows:

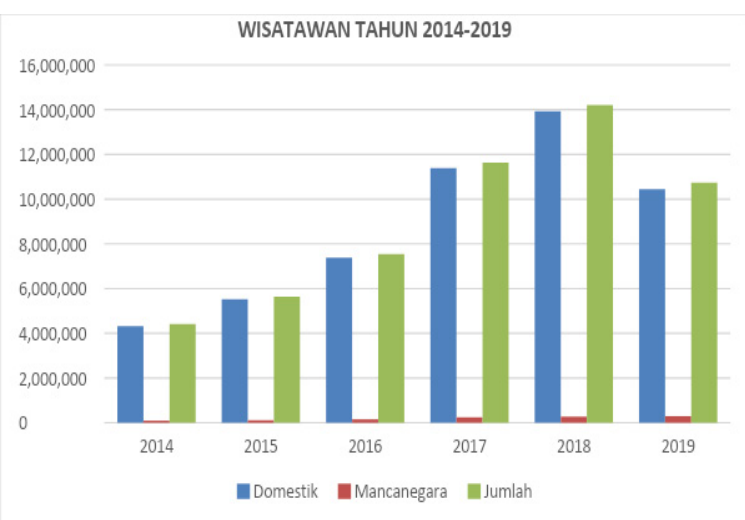

Figure 1. The graph of the development of the number of tourist visits

The tourism sector is very likely to be able to provide economic growth due to the availability of various existing tourism potentials as well as local government support in the form of regulations (Putra, Saepudin, \& Edwin, 2018). The tourism strategy is a leading tourist destination in Indonesia which is the locomotive of development and provides increased welfare to the community, with the tourism strategy:

a. Increasing domestic and foreign tourism promotion activities through a market analysis approach.

b. Coaching and coordination with regencies / cities in order to create tourism products that are ready to sell and strong, able to compete in order to attract interest and tourist attractiveness.

c. Determining the sector tourism as a regional development priority by establishing a tourism development area to support Lampung tourism objects and attractions. d. Encourage investor interest to: invest in the Lampung area.

e. Increase community participation and cultural arts in Lampung to play an active role in regional development and tourism in particular.

The development of tourism in Lampung looks quite good, this is judged by the total tourists who visit and also at the festival. In 2016 there were 31 events, and in 2017 it had 53 events. The event that is included in the National Top 100 Calendar of Event $(\mathrm{CoE})$ is the Lampung Krakatau Festival. In addition, there are five excellent events namely Krui Surf Fest, Stabas Bay Festival, Brak Scale Festival, Way Kambas Festival, and Pahawang Festival (Lampung Province Tourism, 2018). The total number of foreign tourists visiting and also at festivals in Lampung Province has always increased every year. The following is data on foreign tourist visits to Lampung Province in 2015 - 2017:

Table 1. Foreign tourist visits to Lampung Province

\begin{tabular}{ccc}
\hline No & Year & Number Of Foreign Tourism \\
\hline 1. & 2015 & 114,907 people \\
2. & 2016 & 155,053 people \\
3. & 2017 & 245,372 people \\
4. & 2018 & 274.127 people \\
5. & 2019 & 297.469 people \\
\hline
\end{tabular}

Source: (Lampung Tourism Office, 2018)

Seen in table 1 that the visits of foreign tourists to Lampung Province have increased every year. In 2015 the number of foreign tourists reached 114,907 people, and in 2016 it increased by $28 \%$ to 155,053 people. Furthermore, in 2017 the number of foreign tourist visits to Lampung province has increased by $58 \%$ to 245,372 people (Source: LKIP Lampung Province Tourism Office in 2017).

There are many tourist destinations in Lampung, increasing the interest of tourists to visit Lampung. Based on data from the Ministry of Tourism and telecommunication Company, the number of domestic tourists visiting Lampung Province exceeded domestic tourists who visit Bali. In October 2017, Lampung was ranked 9th in the number of visits, namely 8.8 million domestic tourists, while Bali was ranked 11th with 8.5 million domestic tourists. Domestic tourist visits are dominated by Jakarta, South Sumatra, Bengkulu, and Jambi (Source: http: /m.republika.co.id/ p1kjp438 / accessed on 25 August 2018 at 20.30 PM). Based on data from the Lampung Province Tourism Office, domestic tourist visits to Lampung Province in 2015 - 2017 are as follows: 
Table 2. Archipelago tourist visits to Lampung Province

\begin{tabular}{ccc}
\hline No & Year & Number Of local Tourism \\
\hline 1. & 2015 & $5,370,803$ people \\
2. & 2016 & $7,381,774$ people \\
3. & 2017 & $11,395,827$ people \\
4. & 2018 & $13,930.135$ people \\
5. & 2019 & $14,170,452$ people \\
\hline
\end{tabular}

Source: (Lampung Tourism Office, 2018)

It can be seen in table 2 that domestic tourist visits to Lampung Province have increased every year. In 2015, domestic tourists reached 5,370,803 people and an increase in 2016 by $37.4 \%$ to $7,381,774$ people, then in 2017 the number of domestic tourists to tourist destinations increased by $54.4 \%$ to $11,395,827$ people (Lampung Province Tourism Office, 2019).

Encouraging the development of tourism in Lampung, the GenPI Lampung plays an important role in developing tourism in Lampung by carrying out intense promotions on social media, one of which is by sending content on tourist destinations in Lampung to the platform GenPi.co. GenPI Lampung also carries out activities offline, one of which is by creating a digital tourism destination in the form of a market.

Digital tourism destination is the result of the demands of the age digital (Míguez-González \& Fernández, 2015) given rating today dominated generation millennial,tend to like a visit to a destination that gives experience (Liu, Norman, \& Pennington-Gray, 2013). The concept of digital tourism destination refers to creative destinations (Umachandran, Ferdinand, Jurčić, \& Della , 2017), which have spots photogenic to be uploaded on social media, and viral on social media (Ge, 2019).

Survey released Everbrite-Harris Poll in 2016, generations of millennial prefer to spend their money to get the experience (Mistilis, Buhalis, \& Gretzel, 2014) compared to goods (material goods) (Del Chiappa \& Fortezza, 2017). Digital tourism destinations can be in the form of tourist objects, cultural attractions, and culinary, both existing and future ones (Chiarini \& Vagnoni, 2017), as well as digital tourism destinations that have been developed in Lampung, namely Tahura Market in the Tahura Wan Abdul Rachman area.

Tahura Market is a digital tourism destination in Lampung developed by GenPI Lampung. GenPI is a community digital under the auspices of the Ministry of Tourism of the Republic of Indonesia which plays a role in the development of tourism go digital (Dewi \& Issundari, 2016). One of the duties of GenPi Lampung is to help optimize the Lampung program go digital by developing Tahura Market. It is a digital tourism destination with a variety of culinary and culture combined with attractive natural beauty as a photo area to increase tourism in Lampung.

The development of tourism which tends to lead to mass tourism often causes various negative impacts that are not realized. The impact of mass tourism can cause degradation and even top destruction environment, both natural environment and environment cultural and social (Saepudin, 2019)

Tahura Market has a traditional characteristic, namely by selling various kinds of traditional foods such as processed cassava, lepet, gado-Gado, cenil and so on. Tahura Market also provides cultural attractions such as traditional dances, typical Lampung music, archery tours and waterfalls as well as traditional games such as gobaksodor, cranks, tops and so on. Apart from being a tourist spot, Tahura Market is also able to introduce Lampung culture to visiting tourists. Tahura Market management uses social media as a promotional media and markets tourism in Lampung to foreign countries.

The development of the Tahura Market has received a positive response from the community, this can be seen from the number of tourists visiting the Tahura Market and the people around Tahura, especially the people of Hurun Village who participate in the development of the Tahura Market by selling traditional food so that it provides an opportunity to improve the economy of the surrounding community Tahura Market. It is also directly involved in the management of the Tahura Market such as cleaning the Tahura Market, providing facilities and infrastructure, and so on.

The problems found related to this research are inadequate facilities and infrastructure for the development of Tahura Market, such as the damage to the archery tourism area that has not been repaired and the lack of provision of garbage boxes. Many tourists also dispose of garbage inappropriately, such as in the river around the Tahura Market, which makes the Tahura Market less clean, the lack of human resources who cares about tourism, it is necessary for people to be aware of tourism (Elyta \& Nuzulian, 2020) so that implementation digital tourism destinations can run optimally so that Lampung can realize the Lampung program to go digital. According to Winardi (1999) optimization is a measure that causes the achievement of goals, so that the digital tourism destination, namely Tahura Market, can be said to be optimal if in its implementation it is in accordance with the stated goals, namely increasing tourist visits, welfare of the community and developing digital tourism destinations in Lampung, especially in the Tahura Market, Pesawaran Regency. 
This study aims to determine GenPi's strategy in developing a policy digital tourism destination towards Lampung going digital.

\section{METHOD}

The method in this research is qualitative, the location of this research is Tahura Market, Teluk Pandan District, Pesawaran Regency, Lampung Province. The informants in this study were the administrators of GenPi Lampung, two administrators of Tahura Market, and two visitors to Tahura Market tours.

According to Moleong (2013) there are two specific purposes that the researcher wants to achieve in formulating research problems by utilizing focus. First, setting focus can limit studies. Second, the determination of focus serves to meet the inclusion criteria or the entry and exit criteria for information that has just been obtained in the field. So that researchers focus their research on the problems that are the objectives of the study (Maleong, 2013). The focus in this study are as follows: Policy development digital tourism destination efforts to increase for tourism visits and factors that influence the development of digital tourism destinations in an effort to increase tourist visits (study on the optimization of the Lampung Program go digital in Tahura Market, Pesawaran Regency)

Data analysis was carried out in stages: display data, data reduction, and conclusion drawing / verification (Sugiyono, 2011).

\section{RESULT AND DISCUSSION}

\section{General Description of Tourism in Pesawaran Regency.}

Pesawaran regency in Lampung Province which has a coastline and several small islands outside the mainland area. A regency in Lampung is certainly a tourism potential that can drive the regional economy. In order to develop tourism with the tourism potential of Pesawaran Regency, including beach tourism, nature tourism, island tourism, the Pesawaran Regency Government continues to collaborate with the private sector and other stakeholders. The basic thing that is carried out by the Pesawaran District. Government in realizing Bumi Wisata is by providing basic infrastructure in the form of road construction as access to developing tourism potential in Pesawaran District. Ensuring a sense of security and comfort to tourists, and empowering local communities to reduce poverty and unemployment (Hays, Page, \& Burhalis, 2013).

In the context of developing tourism, Pesawaran District has also provided guidance to musicians and talent search in the music field and has formed the
Pesawaran band. The utilization and development of tourism in Pesawaran district and its objects can be carried out according to the existing potential, the types of tourism include:

1. Marine Tourism, in the form of beaches, sea and beaches

2. Tirta Tourism, in the form of rivers and waterfalls

3. Agro Tourism, in the form of coconut plantations oil palm, coffee, rubber, cultured pearl shells and groupers

4. Mountain tourism, in the form of mountains and mountains

5. Nature tourism, in the form of flora and fauna in Taman Hutan Rakyat (TAHURA)

6. Special interest tourism, in the form of snorkeling, diving and mountain bike

7. Cultural tourism, in the form of building architecture/traditional houses, historical and customary relics, historical relics and customs of Lampung.

Visitors to entertainment venues in Pesawaran District tend to experience an increase every year. In 2019, Pahawang Island Tourism Village was the most visited entertainment place for tourists, with 400,320 visitors.

\section{Development of Digital Tourism in The Market Tahura, Teluk Pandan Pesawaran Regency) Input}

Input is all that is needed for implementation of activities that can run smoothly to produce output (Mashun, 2013). Input is related to the resources owned in the development of digital tourism destinations in Tahura Market, Pesawaran District, in carrying out activities in accordance with its vision and mission to achieve predetermined goals and objectives. The resources that are owned in the development of digital tourism destinations in Tahura Market, Pesawaran Regency, namely:

\section{Human Resources}

Human resources have a strategic position in an organization, meaning that the human element plays a very important role in carrying out activities for achievement of objectives. Resources in the development of digital tourism destinations in the Tahura Market are the main drivers in realizing the implementation of every activity in an effort to increase tourist visits.

Human Resources is an important element in an organization (Pasolong, 2011). Human Resources is the driving force of an organization that will determine the good or bad performance of an organization, 
as well as the development of a digital tourism destination in Tahura Market, Pesawaran Regency, as an effort to increase tourist visits and the welfare of the surrounding community. The quality of human resources in these activities is important (Li \& Wang, 2010). Based on research conducted by researchers at the Tahura Market, it is known that activities such as monitoring, directing, accuracy of every trade, making reports, promoting, preparing facilities and infrastructure assigned to GenPI Lampung and the community around Tahura, namely the people of Hurun Village.

Table 3. Distribution of tasks on the development of Tahura Market

\begin{tabular}{cll}
\hline No. & \multicolumn{1}{c}{ Distribution of Tasks } & Number of Members \\
\hline 1 & Tenant & 12 \\
2 & Market Managers & 5 \\
3 & Creative Team & 4 \\
4 & Promotion Media & 4 \\
\hline
\end{tabular}

Source: Data GenPI Lampung, 2018

Through table 3 it can be seen that the number of members in the development of digital tourism destinations in Tahura Market is 25 people. The division of tasks consisted of tenant members totaling 12 traders, 5 market managers, 2 creative team members. From GenPI Lampung and 2 from the Hurun village community, and 4 people from promotional media. Based on the results of interviews conducted by researchers, it is known that the development of digital tourism destinations in the Tahura Market aims to increase tourist visits, but besides that market development also aims to improve the economy of the people around the Tahura market. The community plays an important role in the development of the Tahura Market, but the lack of socialization and knowledge in the field of market management makes the community not good at carrying out their duties and the lack of people who take part in market management.

Thus, based on the results of research reviewed with theory, it can be concluded that in terms of human resources in the Tahura Market, the competence of human resources in the development of digital tourism destinations in the Tahura Market, Pesawaran Regency, is not suitable because people do not get enough training and knowledge so that they do not understand their duties and functions in developing the Tahura market. Apart from that, the number of members of the community is still insufficient to carry out market activities such as selling traditional food. Tahura Market is synonymous with culinary and cultural attractions, but the people around
Tahura who sell only 12 tenants while the tenants provided are 15. If the large number of tourists who visit each week with the provision of culinary attractions, it is currently lacking because tourists will be bored with the provision.

\section{Budget}

One resource that is included in a group of inputs is funding or budget (Mashun, 2013). According to Mardiasmo (Wibowo, 2011) the budget is a statement of estimated performance to be achieved during a certain period of time expressed in financial terms. In developing a digital tourism destination in the Tahura Market, the GenPI Lampung as the implementer of the market development receives funds from the Ministry of Tourism of the Republic of Indonesia. Through this fund, it is hoped that it can create digital destinations, one of which is the management of Tahura Market.

The budget obtained in market management is quite good. The budget, approximately received a budget of seventy million, but this budget is only given at the beginning of market development. Based on the results of the interview, it can be concluded that the budget provided is sufficiently used in market management because the funds are only used for the provision of tenants, entertainment stages, tables and chairs as well as providing photo spots. UPTD/ Regional Integrated Service Unit Tahura Wan Abdul Rachman has provided a place for land, toilets and parking areas. The availability of this budget greatly influences the implementation of activities at the Tahura Market.

\section{Facilities and infrastructure}

One of the resources included in the group input is facilities and infrastructure such as equipment and technology (Mashun, 2013). Based on "Kamus Besar Bahasa Indonesia" (KBBI)/the Big Indonesian Dictionary 1999, means are anything that is used as a means of achieving goals and objectives, while infrastructure is anything that is the main support for the implementation of a process (Poerwadarminta, 1999). In the development of digital tourism destinations, Tahura Market has facilities and infrastructure such as the availability of land, benches and tables, tenants, entertainment stages, archery areas, mck and parking areas. Meanwhile, the means of promotional media are through Instagram, the official GenPI website, and the genpi.co platform application which can be downloaded via Google Play, making it easier for tourists to access information related to destinations digital developed by GenPI, one of which is Tahura Market. The facility is intended 
to support and facilitate the development of digital tourism destinations in Tahura Market, Pesawaran Regency.

Until now, the facilities and infrastructure in Tahura Market are very adequate. Based on research observations, the provision of tables and chairs for visitors is already 20 tables and chairs so that it can be said to be comfortable because visitors can easily sit where they want.

In addition, the facilities and infrastructure owned at Tahura Market in providing entertainment stages are also adequate. Every week there are always performances of cultural attractions that are performed on the stage such as traditional dances, lute music and so on. This is certainly a supporting factor in increasing visits because people are provided with knowledge of traditional culture (Schellhorn, Schellhorn, Matthias, \& Perkins , 2014). Other facilities and infrastructure, namely the availability of adequate parking spaces and parking lots. However, the archery area which is an attractive entertainment area for visitors is damaged and there has been no repair until August 31, 2019. Wibowo (2011) stated that tools or facilities are resources that can be used to help complete tasks successful.

In implementing the development of a digital tourism destination in Tahura Market, has been facilitated with very adequate facilities and infrastructures. This facility has supported and facilitated the implementation of activities at Tahura Market, Pesawaran Regency.

\section{B. Process}

Process is a good measure of activity in terms of speed, permanence and size of the accuracy of the implementation of an activity (Han \& Mills, 2006). This means that every time in developing a digital tourism destination in the Tahura Market, how is it done in developing the Tahura Market, and also choosing the right time.

In this study, researchers focused on two categories, namely the methods used in the development of the Tahura Market and the timeliness of implementation in the development of digital tourism destinations in Tahura Market.

\section{Procedures or methods used in the development of Tahura Market.}

Implementation procedure is a mechanism that is applied to an organization, which includes procedures for carrying out activities that exist within an organization. Based on the implementation results, it is known that the development of digital tourism destinations applies the $3 \mathrm{~A}$ principle (Accessibility,
Amenities, Attractions) in the implementation of its activities. The following is an explanation of how to implement the development of digital tourism destinations in Tahura Market.

\section{a. Accessibility}

According to Carter and Fabricus in Sunaryo (2013), accessibility is not only about the ease of transportation for tourists to reach a tourist spot, but also the time it takes, signposts to tourist locations and other related devices. In the development of digital tourism destinations in Tahura Market, the selection of places is very strategic and not far from the city center. It takes about 30 minutes from the city of Bandar Lampung. In addition, Tahura Market is on the tourist route, making it easier for visitors to find tourist locations and directions are provided.

\section{b. Amenities}

The amenities referred to in developing digital tourism destinations are the availability of facilities and infrastructure, such as benches and tables, tenants, chairs, parking lots, entertainment stages, as well as interesting spots and instagramable photos to be uploaded on social media (Adi, 2014). In addition, promotional means through media digital such as through Instagram, the official GenPI website, and the genpi.co platform application.

\section{c. Attractions}

Carter and Fabricus in (Sunaryo, 2013), attractions are attractions that will generate motivation and desire for tourists to visit tourist objects. Tourist attractions are one way to develop digital tourism destinations in Tahura Market. These attractions consist of culinary attractions, cultural attractions, and the provision of photo spots. Culinary attractions, namely providing a variety of traditional foods ranging from processed cassava, lepet, gado-gado, cenil and so on. In addition there are traditional dance performances, lute music and the provision of traditional games such as hobak sodor, hopscotch, and bosses. Meanwhile, the provision of photo spots is provided with the concept of digital destinations, which are attractive and destinations instagramable to be uploaded on media social so as to create their own attraction for visitors.

In reality in the field and based on the presentation of research results, it can be concluded that the implementation of activities in the development of digital tourism destinations in the Tahura Market has implemented the 3A principle (Accessibility, Amenities, Attractions). Thus, based on the monitoring research reviewed by the theory, the 
researchers considered that the method used in developing the Tahura Market went quite well, this was evidenced by the implementation of the activities carried out in accordance with the principles applied.

\section{d. Timeliness}

Timeliness is an indicator in a process that is very important to measure to determine whether an activity is optimal or not. Based on the implementation research results, the development of a digital tourism destination in Tahura Market, the implementation time is on weekends from 08.00 AM to 17.00 AM. The timing was chosen because the target market in the development of this Tahura market were families, young people, and children, so the election on the weekend was the right time to gather.

Thus, the researcher can judge that the timeliness of developing a digital tourism destination in the Tahura Market has been going well. This is indicated by the selection of the right time for visitor holidays, especially for families, adolescents and children.

\section{e. Output}

Output is something that is expected to be directly reachable from an activity both physical and non-physical form (Jayadi \& Suryawan, 2020). According to researchers, the output in this study is the result of achievements in developing digital tourism destinations as an effort to increase tourist visits in Tahura Market.

Based on the results of the study, the number of tourist visits in the Tahura Market as described in table 7 has increased quite high, seen from before and during the existence of the Tahura Market. It was developed since December 2017 and tourist visits have increased by $154 \%$, namely 6,781 people.

Thus, the researcher can judge that the output of the development of a digital tourism destination in Tahura Market, is quite optimal, because it is based on observations and interviews conducted by researchers and supported by data obtained from UPTD/Regional Integrated Service Unit Tahura. Wan Abdul Rachman noted that the number of tourist visits in Tahura Market has increased. So it can be concluded that the optimization of the Lampung Program go digital in Tahura Market in carrying out the development of digital tourism destinations in the output indicators can be said to be quite good.

\section{f. The results (outcomes)}

Outcome is a reflection of whether or not an output produced an organization. Result indicators are everything that reflects the functioning of the outputs of activities in the medium term that have a direct effect. In this study, the indicators measured consist of:

\section{Achievement of goals}

In an organization certainly has goals that must be achieved (Zainal, 2019), but sometimes there are some achievement of goals that are not in accordance with organizational expectations, the process of achieving goals is an activity that has goals by using planning, directing, organizing, and controlling resources to achieve targets effectively and efficiently (Gretzel, Fesenmaier, \& Formica, 2016). Effective means that goals can be achieved in accordance with planning, while efficient means that existing tasks are carried out correctly, organized, and according to the specified schedule.

Based on the research results conducted by researchers, the achievement of the goal of developing a digital tourism destination in Tahura Market is increasing tourist visits and the welfare of the people around the market. Based on the results of interviews conducted by researchers, tourist visits have increased from before and during the Tahura Market. Tourist visits every week always exceed the target set. In addition, in terms of the welfare of the community, people can participate in selling at the Tahura Market so that it opens job opportunities for people around the market. People always get high income when tourist visits are crowded, so that tourist visits have a very strong influence on the income of people who sell at Tahura Market.

It can be seen that between indicators can have an influence on other indicators so that an activity can run optimally, such as indicators input that help in carrying out work on indicators process. Indicators process that will provide good results on output so that they can achieve goals and have a good impact on society (Nurmi, 2017). The achievement of the goal of developing a digital tourism destination in the Tahura Market, went beyond the predetermined target. Thus, the researcher can judge that the development of a digital tourism destination in the Tahura Market in terms of achieving targets or goals has gone quite well.

\section{Impact on the community broad}

With outcome indicators, the organization will be able to find out whether the results that have been obtained in the form of outputs can be used properly and provide great benefits to society. 
The digital development of tourism destinations in Tahura Market has a positive impact on the economic revival of the surrounding community.

Based on the results of the interview, it can be seen that the development of the Tahura Market has been going quite well and has had a positive impact on the development of digital tourist destinations in the Tahura Market. This condition helps the community from an economic point of view because the Tahura Market provides job opportunities for Hurun Village.

The researchers assess that optimization in the development of digital tourism destinations in the Tahura Market has been going well because according to the accounts of the people who are correspondents in this indicator, they reveal that so far they have felt the impact of the implementation of this activity. Thus, it can be concluded that the development of a digital tourism destination in Tahura Market can be felt by the community regarding its purpose, namely the welfare of the community.

\section{Factors that influence the development of digital tourism destinations in the Tahura Market}

A. Supporting Factors for Development Digital Tourism Destination in the Tahura Market

1. Adequate facilities and infrastructure. The supporting factors for the development of digital tourism destinations in the Tahura Market are adequate facilities and infrastructure. It can facilitate the implementation of the Tahura Market development to achieve the desired goals. Some of the facilities and infrastructure at Tahura Market include tables and chairs for visitors, tenants, an entertainment stage, an archery area, a toilet and a parking area. Facilities and infrastructure such as tables, chairs, tenants, archery areas and entertainment stages were provided by the GenPI side, while the toilet and parking area were provided by UPTD/ Regional Integrated Service Unit Tahura Wan Abdul Rachman. In addition, promotional means throughmedia digital such as Instagram, the official GenPI website, and the genpi.co platform application are adequate and make it easier for tourists to get information related to the Tahura Market.

\section{Easy to reach access}

The next supporting factor is easy access to tourist attractions, the time required, and the provision of directions are needed in the development of a digital tourism destination in Tahura Market. Tahura Market is located in Pesawaran Regency and on a tourist route so that tourists can easily find out the location of Tahura Market. In addition, the location of Tahura Market is not far from the city center of Bandar Lampung, only about 30 minutes if accessed via private vehicle.

B. Inhibiting factors in the development of a digital tourism destination in the Tahura Market

\section{Inadequate}

Human Resources are one of the important factors in carrying out an activity. The Human Resources in the development of the Tahura Market are still minimal and do not know their duties. The community does not yet know their duties due to lack of training and socialization from GenPI Lampung. So that training and socialization should be carried out first so that the existing Human Resources can perform their duties optimally.

2. Weather

Changes in weather can cause a decrease in the level of tourist visits because when it rains visitors tend to be quiet. Lonely visitors will have an impact on the income of the people selling at the Tahura Market.

\section{Provision of Attractions}

The next inhibiting factor is the provision of attractions at the Tahura Market. The provision of attractions such as culinary attractions and provision of archery areas is still inadequate. As in culinary attractions, traditional food sellers tend to be quiet, namely only 7 tenants so that the availability of food alone makes visitors bored. Furthermore, the archery area is one of the areas that attracts visitors but it is damaged and there has been no repair.

In order for the development of tourism in Lampung Province with a contemporary concept through a digital approach to develop effectively, the government must be able to take it seriously and not just discourse by involving related organizations such as Genpi and all Indonesian people, especially the current generation, namely generation z. In addition, to further improve the tourism system in Lampung, it is necessary to collaborate with intelligent people in the digital world (Kim \& Fesenmainer, 2018) and it is necessary to collaborate with other countries so that tourism in Lampung can be better known throughout the world. So that many foreign tourists travel to Lampung and can increase community and regional income. 


\section{CONCLUSION}

The policy for developing a digital tourism destination in Tahura Market has been implemented quite well. This can be seen through: (a) input, in its implementation it includes the availability of human resources that is still minimal and some existing human resources do not understand their duties; (b) the Process, in its implementation, includes procedures or methods for developing digital tourism destinations in the Tahura Market. It is seen that the implementation of the Tahura Market has implemented the 3A principle (Accessibility, Amenities, and Attractions); (c) output, in its implementation includes tourist visits at the Tahura Market, has been optimal, this can be seen from the number of tourist visits that have increased from before and during the Tahura Market. Since the existence of Tahura Market in December 2017, tourist visits in 2018 have increased quite high, namely 6,781 people; (d) the results (outcome), overall the implementation has gone well and according to the indicators of assessment, namely the achievement of the goal of developing the Tahura Market in increasing tourist visits has gone quite well in increasing tourist visits and the welfare of the community around Tahura.

\section{REFERENCES}

Adi, S. (2014). Evaluation on the effectiveness of the web technology usage in promoting and marketing Indonesia tourism. Journal of Theoretical and Applied Information Technology 68(3):622-629.

Ahmad, A. (2018). Pengaruh Citra Destinasi Terhadap Intensi Wisatawan Berkunjung. Sosiohumaniora- Jurnal Ilum-ilmu sosial dan humaniora 20 (3):207-214.

Chiarini, A., \& Vagnoni, E. (2017). Strategic management of industry 4.0. An exploratory research. Value Co-Creation: management challenges for business and society:220-224.

Del Chiappa, G., \& Fortezza, F. (2017). Analisi delle motivazioni alla base del turismo matrimoniale: un'indagine esplorativa. Sinergie Italian Journal of Management 34 (101):141-157.

Della, C., Sciarrelli, M., \& Del Gaudio, G. (2015). Customer satisfaction in tourist destination: The case of tourism offer in the city of Naples. Journal of Investment and Management vol. 4 (1-1):39-50.
Dewi, M., \& Issundari, S. (2016). Desa Wisata sebagai Aset Soft Power Indonesia. Masyarakat, Kebudayaan Dan Politik, 29(2): 68-78.

Elyta, \& Nuzulian, U. (2020). Diplomasi Indonesia Berbasis Program Cross Border Tourism dalam Meningkatkan Kunjungan Wisatawan Mancanegara. Insignia: Journal of International Relations 7(1):, 1-16.

Ge, J. (2019). Social Media-Based visual humour use in tourism marketing: A semiotic perspective. Eur. J. Humour Res 7: 6-25.

Gretzel, U., Fesenmaier, \& Formica, S. (2016). Searching for the future: challenges faced by destination marketing organizations. Journal of Travel Research 45(2):116-126.

Han, J., \& Mills, J. (2006). Zero acquaintance benchmarking at travel destination websites: what is the first impression that national tourism organizations try to make? International Journal of Tourism Research 8(6): 405-430.

Hays, S., Page, S., \& Burhalis, D. (2013). Social media as a destination marketing tool: its use by national tourism organisations. Current issues in Tourism16 (3):211-239.

Heliany, I. (2019). Wonderful Digital Tourism Indonesia DanPeran Revolusi Industri Dalam Menghadapi Era Ekonomi Digital 5.0. Destinesia Jurnal Hospitaliti dan Pariwisata 1 (1): 21-35.

Jayadi, M., \& Suryawan, I. (2020). Strategi Pengembangan Potensi Pariwisata Di Pantai Blimbingsari Kabupaten Banyuwangi. Jurnal Destinasi Pariwisata 8 (1): 1-16.

Kim, H., \& Fesenmainer, R. (2018). Persuasive design of destination web sites: An analysis of first impression. Journal of Travel research 47(1):313.

Lampung Province Tourism. (2018, Desember 20). Lampungprov.go.id/wisatawan-ke-lampungmeningkat. Retrieved Agustus 25, 209, from Lampungprov.go.id/wisatawan-ke-lampungmeningkat.

Lampung Province Tourism Office. (2019, Desember 20). Lampungprov.go.id/wisatawan-kelampung-meningkat. Retrieved Agustus 25:209, from Lampungprov.go.id/wisatawanke-lampung-meningkat.

Larsen, S., \& Wolff, K. (2016). Exploring assumptions about cruise tourists' visits to ports. Tourism Management Perspectives 17: 44-49. 
Li,X., \&Wang,Y.(2010). Evaluating the effectiveness of destination marketing organisations' websites: Evidence from China. International Journal of Tourism Research 12(5):536-549.

Liu, B., Norman, W., \& Pennington-Gray, L. (2013). A flash of culinary tourism: Understanding the influences of online food photography on people's travel planning process on flickr. Tour. Cult. Commun. 13: 5-18.

Maleong, L. (2013). Metode Penelitian Kualitatif. Bandung (ID): Remaja Rosda Karya.

Mashun. (2013). Pengukuran Kinerja Sektor Publik. Yogyakarta (ID): BPPE.

Meiwany, B., Tapatfeto, K., \& Juita, L. (2018). Strategi Pengembangan Objek Wisata Dalam Upaya Peningkatan Kunjungan. Jurnal of Management 6:1020.

Míguez-González, \& Fernández, C. (2015). J. Tourism and online communication: Interactivity and social web in official destination websites. Commun. Soc 18: 17-31.

Mistilis, N., Buhalis, D., \& Gretzel, U. (2014). Future eDestination Marketing: Perspective of an Australian Tourism Stakeholder Network. J. Travel Res. 53: 778-790.

Nurhadi, F. (2014). Strategi Pengembangan Pariwisata Oleh Pemerintah Daerah Terhadap Pendapatan Asli Daerah (PAD) (Studi Pada Dinas Pemuda, Olahraga, Kebudayaan Dan Pariwisata Kabupaten Mojokerto). Jurnal Administrasi Publik Mahasiswa Universitas Brawijaya 2 (2):325-331.

Nurmi, N. (2017). Membangun Website Sistem Informasi Dinas Pariwisata. Jurnal Edik Informatika 1(2), 1-6.
Pasolong, H. (2011). Teori Administrasi Publik. Bandung (ID): Alfabeta.

Poerwadarminta, W. (1999). Kamus Umum Bahasa Indonesia. Jakarta (ID): Balai Pustaka.

Putra, F. K., Saepudin, P., \& Edwin. (2018). Digital Tourism: A Content Analysis of West Java Tourism Websites. Journal of Indonesian Tourism and Development Studies.6 (2)

Saepudin, e. (2019). Pengembangan Desa Wisata di desa Cibodas. Sosiohumaniora, Jurnal Ilmuilmu Sosial dan Humaniora 21 (1):1-10.

Schellhorn, M. a., Schellhorn, Matthias, \& Perkins , C. (2014). Representations of native culture and traditional lifestyle are stereotyped and stress ecological and cultural unchangedness. Current Issues in Tourism 7 (2): 95-133.

Sugiyono. (2011). Metode Penelitian Kuantitatif, Kualitatif, Dan Kombinasi (Mixed Methods). Bandung (ID): Alfabeta.

Sunaryo, B. (2013). Kebijakan Pembangunan Destinasi Pariwisata: Konsep dan aplikasinya di Indonesia. Yogyakarta (ID): Gava Media.

Umachandran, K., Ferdinand, D., Jurčić, \& Della , C. (2017). e-commerce: A Social Engagement Tool. OSR Journal of Economics and Finance (IOSR-JEF), 8(5): 60-64.

Wibowo. (2011). Manajemen Kinerja. Jakarta (ID): PT. Rajagrafindo.

Zainal, A. (2019). Pengaruh Media Video Tentang Pariwisata Di Kabupaten Pesawaran Terhadap Peningkatan Pengetahuan Mahasiswa. Jurnal Master Pariwisata (JUMPA) 06 (01):202218. 